\title{
INSTITUTION OF A COURT PROBATION OFFICER in The Polish administration of JUSTiCe
}

\author{
INSTYTUCJA KURATORA SĄDOWEGO \\ W POLSKIM WYMIARZE SPRAWIEDLIWOŚCI
}

\begin{abstract}
The court guardianship for minors and adults, shaped in the course of numerous changes, is nowadays one of the key elements of the resocialising education system. The Board of Trustees perfectly combines institutions and specializations that have functioned in isolation from each other for decades. Court superintendents carry out tasks defined by law, which are related to the execution of court decisions. A distinction is made between professional and social curators. Curatorial teams are located at penal, family and youth departments. The court superintendent for adults is subject to criminal law procedure, while the family superintendent is subject to civil law procedure. A systemic approach to the problem requires a comprehensive approach, taking into account not only the individual, but also the surrounding systems, including in particular family and local systems. Currently, the cooperation of curators with representatives of various services is clearly visible, which translates positively not only into the functioning of the wards, but also of the entire local community.
\end{abstract}

\section{STRESZCZENIE}

Ukształtowana w toku licznych zmian kuratela sądowa dla nieletnich i dorosłych stanowi dziś jeden z kluczowych elementów systemu wychowania resocjalizującego. Kuratela doskonale łączy instytucje i specjalizacje, które przez dziesięciolecia funkcjonowały w izolacji od siebie. Kuratorzy sądowi realizują określone przez prawo zadania, które są związane z wykonywaniem orzeczeń sądu. Wyróżnia się kuratorów zawodowych i społecznych. Zespoły kuratorskie są usytuowane przy wydziałach kar- 
nych oraz rodzinnych i nieletnich. Kurator sądowy dla dorosłych podlega procedurze karnoprawnej, natomiast kurator rodzinny procedurze cywilnoprawnej.

KEYWORDS: probation officer, supervision, court superintendent, law on court superintendents, guardianship

SŁOWA KLUCzOWE: kurator sądowy, kuratela, dozór, nadzór, ustawa o kuratorach sqdowych

\section{WPROWADZENIE}

Służba kuratorska jest jedną z najstarszych w Polsce. Na kuratorach skupia się główny ciężar wykonywania i nadzorowania wszystkich sankcji oraz środków, które stanowią alternatywę dla izolacji i umieszczenia podsądnych poza środowiskiem rodzinnym. Taka opieka prawna ustanowiona przez sąd ma wieloletnią tradycję. Jej początki sięgają okresu międzywojennego. Rozwój kurateli pozostawał w ścisłym związku ze skomplikowanymi dziejami Polski, jednak wypracowane modelowe rozwiązania określające usytuowanie, funkcje i zadania kuratorów sądowych okazały się bardzo trwałe. Intencją autora jest ukazanie obrazu zmieniającego się modelu kurateli sądowej na przestrzeni wieku oraz określenie współczesnej roli kuratora sądowego w systemie resocjalizacji. W niniejszym artykule, opartym na literaturze przedmiotu, zostaną omówione zadania kuratorów sądowych, ich prawa i obowiązki oraz działania profilaktyczno-wychowawcze, czyli wszystko, co w toku zmian ustrojowych wpisało się w zakres ich pracy. Artykuł został oparty na literaturze przedmiotu oraz przepisach prawnych na dzień 30 stycznia $2019 \mathrm{r}$.

\section{Historia powstania zaWodu}

Niektórzy badacze doszukują się źródeł prawnych instytucji kuratora już w średniowieczu, przywołując prawo króla Athelstana z 940 r., które stanowiło, że nieletni poniżej 15. roku życia podlegający każe śmierci nie może być poddany tej egzekucji, lecz oddany na dozór do biskupa (Kalinowski, 1990, s. 284). Późniejsze poszukiwania rozwiązań w dziedzinie postępowania $\mathrm{z}$ wykolejonymi społecznie dziećmi doprowadziły do wyodrębnienia się na przełomie XIX i XX w. specjalnego sądownictwa dla nieletnich. Pierwszy taki sąd powstał w Stanach Zjednoczonych w 1899 r., a na terenie Europy 
w Anglii (1905) i Danii, potem na Węgrzech, w Austrii i Niemczech, Rosji, Portugalii, Belgii, Francji i Szwajcarii (Kowalska-Ehrlich, 1979, s. 228). Interpretowanie angielskiego Common Law wykształciło w XIX w. kilka różnych odmian procedury sądowej, pozwalającej zawieszać sam wymiar kary bądź też jej wykonanie na okres próbny ( $\mathrm{z}$ ang. probation) ${ }^{1}$. Warunkowe pozostawienie na wolności wymagało jednak kontroli, stąd też zrodziła się instytucja kuratora sądowego (probationofficer), który sprawował dozór nad podsądnym. Rozwój systemu wolności dozorowanej w Europie rozwijał się równolegle z rozwojem sądownictwa dla nieletnich. Odrębnym torem poszły państwa skandynawskie, oddając sprawy nieletnich w ręce specjalnych organów administracyjno-społecznych, tzw. komisji rad bądź komitetów opieki nad dziećmi i młodzieżą. Wypracowały one metody postępowania podobne do probation. W Europie Środkowej największy wpływ miały jednak ustawodawstwa Belgii i Francji. Zaczęto wprowadzać tam tzw. zawieszenie proste oznaczające zawieszenie orzeczonej kary pozbawienia wolności. Przy czym z owym zawieszeniem nie wiązały się żadne obowiązki ani dozór dla skazanego. To rozwiązanie w XX w. przyjęły prawie wszystkie ustawodawstwa karne Europy kontynentalnej, również Polska. Warto zauważyć, że anglo-amerykańska probacja oraz europejska procedura zawieszenia wykonania kary już orzeczonej, w gruncie rzeczy były do siebie podobne. Istotą obu było pozostawienie skazanego na wolności. Jednak system anglo-amerykański przewidywał kontrolę formalną, przybierającą postać dozoru, w modelu europejskim zaś takiej kontroli nie było. W Anglii posługiwano się nazwą probation, w Stanach Zjednoczonych probation lub parol. Rozwiązanie francuskie nazwano natomiast sursissimple, czyli zawieszeniem prostym. System probation w początkach XX w. nie zdobył jednak w Europie większej popularności. Z tego powodu w 1904 r. zastąpiono go francusko-belgijskim systemem libertésurveillée (wolność dozorowana). Zasadnicza różnica między tymi systemami polegała na tym, że dozory w ramach systemu probation od 1907 roku zaczęła sprawować zawodowa służba probacyjna, natomiast wykonywanie dozorów w ramach libertésurveillée powierzano ochotnikom (Jurczyk, 2017, s. 17).

Sprawami nieletnich w Polsce zaczęto interesować się pod koniec XVIII w. za sprawą działalności Komisji Edukacji Narodowej, która opracowała cztery 
projekty modyfikacji norm prawnych dotyczących opieki i opiekunów małoletnich (Marzec-Holka, 1994, s. 146).W 1919 r. nastąpiło powołanie do życia sądów dla nieletnich (Szymków, 2018, s. 61-82; Dz.Praw Nr 63, poz. 378), a przy tych sądach - urzędu stałego opiekuna sądowego (Borowski i Wysocki, 2001, s. 137). Sama idea powołania instytucji kuratora była wyrazem sięgania przez polskiego prawodawcę do rozwiązań istniejących w innych państwach (Dz.Praw z 8 lutego 1919 r. nr 14, poz. 171). Pierwsze sądy dla nieletnich, które powstały w Warszawie, Łodzi oraz w Lublinie, miały orzekać w sprawach karnych nieletnich do ukończenia przez nich 17. roku życia. W pozostałych miastach sprawy nieletnich były rozpatrywane przez sądy powszechne, wspierające proces resocjalizacji nieletnich. Od tego momentu sądownictwo dla nieletnich zostało ujęte w struktury prawne. Zakres obowiązków „opiekunów prawnych” wyznaczały czynności o charakterze opiekuńczo-wychowawczym oraz diagnostycznym (zbieranie informacji o nieletnich na potrzeby sądu). Opiekunowie sądowi byli opłacani z tzw. funduszu dyspozycyjnego sądu (Rapa, 2012, s. 116). Należy zaznaczyć, że zaledwie 3 miesiące wcześniej Polska odzyskała niepodległość, po ponad 123 latach niewoli, stąd w poszczególnych dzielnicach państwa polskiego obowiązywały przepisy państw zaborczych, często różniące się między sobą. Wypracowanie nowych, jednolitych zasad odpowiedzialności nieletnich stało się jedną z pierwszych kwestii, jakimi zajęła się Komisja Kodyfikacyjna. Skończyło się jednak na projektach. Należy zwrócić uwagę, że powołanie sądownictwa dla nieletnich nastąpiło przed ustanowieniem nowych zasad odpowiedzialności nieletnich, ponieważ Kodeks postępowania karnego wszedł w życie w 1928 r., a Kodeks karny dopiero w 1932 r. W okresie dwudziestolecia międzywojennego nie doczekano się stosownej ustawy. Wybuch II wojny światowej wstrzymał rozwój kurateli sądowej, jak również wszystkich instytucji państwowych, i dopiero w 1949 r. przystąpiono do organizowania sądów dla nieletnich oraz powoływania przy tych sądach kuratorów dla nieletnich. Byli to wyłącznie kuratorzy społeczni. Systematycznie rozszerzano zakres działania i kompetencji kuratorów oraz ich profesjonalizacji. Obok kuratora dla nieletnich powołano także inspektorów społecznych władzy opiekuńczej. Dnia 30 marca 1951 r. Minister Sprawiedliwości wydał rozporządzenie o kuratorach sądowych dla nieletnich (Dz.U. nr 25, poz.188), 
które podtrzymywało społeczny charakter kurateli wprowadzony w okresie międzywojennym. Zasadniczy przełom w obszarze funkcjonowania aparatu kurateli rodzinnej nastąpił w 1959 r., gdy wprowadzono 3 akty prawne, które doprowadziły do przełomu organizacyjnego tej instytucji:

1. Rozporządzenie Ministra Sprawiedliwości z 13 lutego 1959 r. o kuratorach sądowych dla nieletnich (Dz.U. nr 18, poz. 113),

2. Rozporządzenie Ministra Sprawiedliwości z 1 kwietnia 1959 r. w sprawie wynagradzania kuratorów zawodowych dla nieletnich (Dz.U. z 1959 r. nr 26, poz. 164),

3. Zarządzenie - Instrukcja w sprawie kuratorów sądowych dla nieletnich wydana 10 kwietnia 1959 r. przez Ministra Sprawiedliwości, która precyzowała wymagania wobec kandydatów na kuratorów (Rapa, s. 118; Górecki, 1997, s. 28).

Początkowo kuratorzy byli pomocnikami sędziego w zbieraniu informacji o nieletnich na potrzeby postępowania sądowego, opiekowali się nieletnimi pozbawionymi opieki rodzicielskiej oraz sprawowali nadzór nad nieletnimi skazanymi na karę, a korzystającymi z dobrodziejstwa zawieszenia kary (Dz.U. z 1919 r. nr 63, poz. 378). Od 1973 r. obowiązki obu tych organów wykonywał kurator dla nieletnich (Kwadrans, 2010, s. 122). W sądownictwie dla dorosłych powoływano kuratorów sądowych dla nadzoru nad warunkowo zwolnionymi, a następnie kuratorów sądowych dla dozoru ${ }^{2}$ ochronnego nad osobami, którym wykonanie kary warunkowo zawieszono (Kufel, 2011, 133-148).

Wraz z ustawą z 26 października 1982 r. o postępowaniu w sprawach nieletnich znacznie rozszerzono zadania dla sędziów i kuratorów w zakresie szeroko pojętej profilaktyki, a zwłaszcza zapobiegania demoralizacji (Kalinowski, 1990, s. 26). Wskutek nowelizacji ustawy o ustroju sądów powszechnych specjalności kuratorów dla nieletnich i dorosłych określono wspólną nazwą: kurator sądowy. Kuratorzy dla nieletnich zostali nazwani kuratorami rodzinnymi, natomiast kuratorzy osób pełnoletnich - kuratorami dla dorosłych. W kolejnych latach pojawiały się próby określenia statusu społeczno-zawodowego kuratorów, czego efektem było przyjęcie ustawy z 27 lipca 2001 r. o kuratorach sądowych (Dz.U. z 2001 r. poz. 1071)33. 
Kandydatom do zawodu postawiono bardzo wysokie wymagania dotyczące przygotowania zawodowego oraz predyspozycji i kwalifikacji osobowościowych i moralnych.

Profil rozwoju instytucji kurateli rodzinnej w Polsce trwał kilkadziesiąt lat i w znacznej mierze zależał od podejmowanych inicjatyw ustawodawczych. Urzeczywistnianie się idei wolności dozorowanej następowało w następujących etapach:

1) 1919-1939 - powstanie kurateli sądowej dla nieletnich,

2) 1949-1973 - reorientacja modelu kurateli dla nieletnich ze społecznego na społeczno-zawodowy,

3) 1977-1978 - powołanie Sądów Rodzinnych i dla Nieletnich,

4) 1982-1986 - ustanowienie funkcji kuratora sądowego,

5) od 1990 - ukształtowanie zawodowo-społecznego modelu instytucji kurateli rodzinnej (Rapa, 2012, s. 120-121).

Warto podkreślić, że podwaliny pod system probacji położono na początku lat 30. ubiegłego wieku. W Kodeksie karnym z 1932 r. przewidziano możliwość oddania skazanych, wobec których wykonanie kary warunkowo zawieszono, pod dozór ochronny osób lub instytucji (Dz.U. z 1932 r. nr 60, poz. 571, art. $62 \S 1$ ). Od tego momentu w polskim porządku prawnym zaczął kształtować się profil kurateli dla dorosłych, w który przebiegał w następujących etapach:

1) 1932 - zmiany w kodyfikacji karnej wprowadziły możliwość stosowania dozoru w stosunku do skazanych $\mathrm{z}$ warunkowym wykonaniem kary pozbawienia wolności,

2) 1957 - powołanie kuratorów sądowych dla nadzoru nad warunkowo zwolnionymi jako społeczny organ pomocniczy sądu (kuratela społeczna),

3) 1965 - powołanie kuratorów zawodowych w celu dozoru ochronnego nad osobami, wobec których wykonanie kary zawieszono lub które zostały warunkowo zwolnione z zakładów karnych (kuratela zawodowa),

4) 1971 - organizacja kurateli dla dorosłych $z$ wyeksponowaniem roli kuratora sądowego jako odpowiedzialnego merytorycznego organu sądowego wykonującego orzeczenia, 
5) 1982-1985 - podniesienie rangi zawodu kuratora przez nadanie mu statusu ustawowego, wprowadzenie odrębnego nazewnictwa dla kuratorów pracujących przy wydziałach rodzinnych i karnych; doprecyzowanie statusu prawnego,

6) 1986 - wydanie rozporządzenia Ministra Sprawiedliwości w sprawie kuratorów sądowych (Dz.U. z 1986 r. nr 43, poz. 212 ze zm.), umocowanie kurateli w wymiarze sprawiedliwości, usystematyzowanie kompetencji i zadań kuratora sądowego, utrzymanie modelu kurateli społeczno-zawodowej,

7) 1992 - zmiana modelu kurateli sądowej na zawodowo-społeczny,

8) 1997 - uchwalenie ustawy Kodeks karny, Kodeks postępowania cywilnego, Kodeks karny wykonawczy,

9) 1998-2000 - prace nad ustawą o kuratorach sądowych,

10) 2001 - wprowadzenie ustawy o kuratorach sadowych, określenie formy i zakresu działania kurateli sądowej.

W piśmiennictwie znaleźć można wiele odniesień do historii kurateli sądowej w Polsce. Należy tutaj wymienić m.in.: Mariana Kalinowskiego (1984), Piotra Stępniaka (1992), Krystynę Gromek (2002), Tadeusza Jedynaka (2009), Marię Pawlicką (2007) oraz Krzysztofa Stasiaka (2008, 2009).

Kuratela funkcjonująca $\mathrm{w}$ ramach rodzimego systemu wymiaru sprawiedliwości była początkowo $\mathrm{w}$ strukturach sądowych marginalizowana do pełnienia zadań administracyjnych i sprawozdawczo-kontrolnych. Z czasem została przekształcona w profesjonalną służbę pedagogiczną realizującą wiele zadań na każdym etapie postępowania sądowego. Sprawne funkcjonowanie tej grupy zawodowej jest niezmiernie istotne, gdyż skuteczność wielu zmian prawa w zakresie prawa karnego czy postępowania wobec nieletnich zależy od sposobu działania kuratorów sądowych. Kuratorzy stanowią grupę zawodową działającą w obrębie wymiaru sprawiedliwości i zaspokajającą jego potrzeby. Ukształtowana w toku licznych zmian kuratela dla nieletnich i dorosłych stanowi dziś jeden z kluczowych elementów systemu wychowania resocjalizującego. Specyficzne jest to, że choć kuratorzy stanowią pod względem organizacyjnym i funkcjonalnym wspólny element systemu prawnego, to są osadzeni w różnych jego strukturach. Zespoły kuratorskie usytuowane 
są przy wydziałach karnych oraz rodzinnych i nieletnich. Kuratora sądowego dla dorosłych wiąże procedura karnoprawna, natomiast kurator rodzinny podlega procedurze cywilnoprawnej. Inny jest także obszar zadaniowy w obydwu kuratelach.

\section{CharaKterystyKa PRACY WSPÓŁCZESNYCH KURATORÓW}

Występują dwie odmiany zawodowych kuratorów sądowych: kuratorzy dla dorosłych - będący samodzielnym organem postępowania wykonawczego, sprawujący dozory w sprawach karnych na podstawie Kodeksu karnego i Kodeksu karnego wykonawczego oraz kuratorzy rodzinni - sprawujący nadzory w sprawach rodzinnych i nieletnich, działający na podstawie ustawy o postępowaniu w sprawach nieletnich, a także nadzory alkoholowe sprawowane na podstawie przepisów szczególnych, m.in. ustawy o wychowaniu w trzeźwości (Borowski i Wysocki, 2001, s. 138-139). Z podziałem tym wiąże się kolejne rozróżnienie. W odniesieniu do nieletnich oraz w sprawach opiekuńczych rodzinni kuratorzy sądowi sprawują nadzory, natomiast skazani dorośli obejmowani są dozorem. Wszystkie działania podejmowane przez kuratorów sądowych zarówno dla dorosłych, jak i rodzinnych powinny mieć na celu dobro podopiecznego i jego prawidłowe funkcjonowanie w społeczeństwie. Kurator w sensie społecznym działa na rzecz pojednawczego zakończenia konfliktu, który stał się materialną podstawą ingerencji wymiaru sprawiedliwości, oraz pracuje na rzecz pojednania, aby przywrócić ład, bezpieczeństwo i sprawiedliwość (Królikowska, 2006, s. 271-285). Kuratorzy jako organ pomocniczy sądu odgrywają rolę wychowawczą, resocjalizującą, kontrolną i profilaktyczną. Realizując swoje zadania, wykonują je głównie w środowisku podopiecznych, zarówno na wolności, jak i w zakładach zamkniętych czy placówkach opiekuńczo-wychowawczych. Praca kuratora wymaga szczególnych predyspozycji. Jest niezwykle odpowiedzialna i trudna. „Wielkim przywilejem kuratora jest to, że może czasami widzieć autentycznie pozytywne skutki swoich działań dla konkretnych ludzi, swoich podopiecznych, co jest sukcesem jego oraz wymiaru sprawiedliwości, a także całego społeczeństwa. Jednak nieuchronnym doświadczeniem pracy kuratora są porażki, których do końca uniknąć się nie da" (Utrat-Milecki, 
2010, s. 168). We współczesnym piśmiennictwie znaleźć można różnorodne publikacje odnoszące się do aktualnych dylematów i zagadnień kurateli sądowej. Na uwagę zasługują m.in. opracowania Pawła Bachmata (2010), Witolda Mazurka (2014), Andrzeja Bałandynowicza (2015) Marka Konopczyńskiego (2016), Krzysztofa Stasiaka (2018). Autorzy przedstawiają kilka punktów widzenia na nowoczesną rolę kurateli sądowej. Zwracają uwagę m.in. na potrzebę usytuowania jej w systemie pomocy społecznej, która z samej definicji jest bliższa podopiecznym niż sąd, czy też na nowoczesną teorię kary, opartą na paradygmacie sprawiedliwości formalnej, ekwiwalentnej i naprawczej. Ukazują też zależności i dylematy wzajemnego oddziaływania na siebie kuratorów i ich podopiecznych oraz aspekty roli zawodowej związane z ocenami i wartościami decydentów.

W Polsce można zauważyć co najmniej dwie wyraźne postawy społeczne i polityczne wynikające głównie z posiadanych orientacji aksjologiczno-normatywnych będących efektem łączenia doświadczeń historycznych z przemianami cywilizacyjno-kulturowymi. Pierwsza perspektywa poznawcza uznaje dewiacyjne funkcjonowanie jako zło samo w sobie, gdzie najskuteczniejszą drogą do poprawy sytuacji jest zwiększenie represyjności moralnej obyczajowej i organizacyjno-funkcjonalnej, a więc i prawno-karnej. U podłoża tego stanu rzeczy leży fałszywe przekonanie, że zwiększanie surowości przepisów prawnych przyczynia się do zmniejszenia liczby przestępców oraz większej skuteczności w ich resocjalizowaniu. Ta teza jest mocno zakorzeniona w świadomości społecznej i współtworzy określony klimat instytucjonalny w ośrodkach resocjalizacyjnych, co w praktyce oznacza nadmierne stosowanie środków prewencyjno-karnych, niewspółmiernych do potrzeb i okoliczności. Druga perspektywa poznawcza skłania do traktowania przestępczości jako naturalnego i nieuniknionego procesu spowodowanego współczesnymi przeobrażeniami cywilizacyjnymi i gospodarczymi. Tłumaczy się to okolicznościami zewnętrznymi, np. wadliwym funkcjonowaniem rodziny, złą szkołą, dużą dostępnością informacji w Internecie, rozbieżnościami ekonomicznymi itp. Przeciwnicy zwiększania represyjności i surowości działań wymiaru sprawiedliwości w odniesieniu do osób łamiących normy prawne proponują rozwiązania o charakterze terapeutyczno-wychowawczym. Ten sposób myślenia utrwala przekonanie społeczne, że przestępczość i patologie 
są chorobami społecznymi, wobec czego powinny mieć charakter leczniczy, a nie karno-formalny.

$\mathrm{Z}$ jednej strony co jakiś czas wybrzmiewają żądania zaostrzenia represji wobec jednostek niedostosowanych społecznie, a $z$ drugiej podejmowane są próby rezygnacji z karalności niektórych czynów np. posiadania narkotyków. Bałandynowicz twierdzi, że „Nowoczesna teoria kary opiera się na paradygmacie sprawiedliwości formalnej, ekwiwalentnej i naprawczej, dających podstawę do dywersyfikacji środków karnych w tym realizacji probacji w szerokim zakresie jako nowoczesnego systemu sprawiedliwego karania, rozumianego jako wielopasmowa teoria resocjalizacji z udziałem społeczeństwa w środowisku lokalnym i udostępnienia właściwych form opieki terapii probacyjnej, jako systemu oddziaływań zmierzających do integracji i inkluzji społecznej" (Bałandynowicz 2015).

Kuratorzy sądowi realizują określone przez prawo zadania, które związane są z wykonywaniem orzeczeń sądu. Wyróżniamy kuratorów zawodowych i społecznych oraz kuratorów dla dorosłych (którzy wykonują orzeczenia w sprawach karnych) i kuratorów rodzinnych (wykonujących orzeczenia w sprawach rodzinnych i nieletnich). Kuratorzy zawodowi są nadzorowani przez kuratora okręgowego (Ustawa, 2011, art. 35 ust. 1 i 2). Funkcjonują oni na szczeblu sądów rejonowych w ramach „zespołów” koordynowanych przez kierowników - kuratorów wyróżniających się zdolnościami organizacyjnymi i przynajmniej 5-letnim stażem pracy. Kuratorzy społeczni podlegają kuratorom zawodowym, którzy mają obowiązek organizacji i kontroli ich pracy (Ustawa, 2001, art. 11).

Zawodowy kurator sądowy, którego głównym celem jest doprowadzenie do zgodnego z decyzją sądu i respektującego godność wszystkich osób zakończenia konfliktu będącego podstawą interwencji, intensywnie współpracuje ze środowiskiem lokalnym. W realizacji zadań szuka sojuszników wśród różnych instytucji z zakresu pomocy społecznej oraz profilaktyki i resocjalizacji, przeciwdziałania problemom społecznym, pomocy rodzinie i dziecku, a także działającym na rzecz porządku i bezpieczeństwa publicznego. Współpracuje $\mathrm{z}$ organizacjami pozarządowymi stawiającymi sobie zbliżone cele. W tym sensie nie tylko bezpośrednio oddziałuje na podopiecznego i wykonuje samodzielnie funkcje diagnostyczne, profilaktyczno-resocjalizacyjne 
i kontrolne, ale też do pewnego stopnia podejmuje działania organizacyjne oraz koordynujące pracę różnych służb i osób, wykorzystując ich aktywność dla realizacji swoich zadań (Jedynak i Stasiak, 2008). Kurator zawodowy podlega prezesowi sądu okręgowego, do którego kierowane są wnioski kuratora okręgowego dotyczące mianowania, odwołania, przeniesienia lub zawieszenia w czynnościach kuratora zawodowego.

Kuratorem zawodowym może zostać osoba, która:

1) posiada obywatelstwo polskie i korzysta z pełni praw cywilnych i obywatelskich,

2) jest nieskazitelnego charakteru,

3) posiada stan zdrowia pozwalający na wykonywanie obowiązków kuratora zawodowego,

4) ukończyła studia wyższe magisterskie z zakresu nauk pedagogiczno-psychologicznych, socjologicznych, prawnych lub innych wyższych magisterskich z zakresu wymienionych nauk,

5) odbyła aplikację kuratorską,

6) zdała egzamin kuratorski; w szczególnych przypadkach na wniosek prezesa sądu okręgowego przez Ministra Sprawiedliwości może być zwolniona z aplikacji i egzaminu (Ustawa, 2001, art. 5).

Kurator wykonuje swoje obowiązki w terenie oraz pełni dyżury sądowe (Ustawa, 2001, art. 13). Nie może podejmować dodatkowego zatrudnienia bez zgody prezesa sądu okręgowego, a także innego sposobu zarobkowania, które przeszkadzałoby w pełnieniu obowiązków kuratora lub mogło osłabiać zaufanie do jego bezstronności lub podważać zaufanie do sądu (Ustawa, 2001, art. 15). Między kuratorami zawodowymi nie może istnieć stosunek bezpośredniej podległości służbowej (Ustawa, 2001, art. 22). W razie tymczasowego aresztowania kurator zawodowy zostaje zawieszony w pełnieniu obowiązków służbowych (Ustawa, 2001, art. 23). W razie wszczęcia przeciwko kuratorowi zawodowemu postępowania dyscyplinarnego prezes sądu okręgowego może go zawiesić w pełnieniu obowiązków służbowych, przy czym zawieszenie to nie może trwać dłużej niż 3 miesiące (Ustawa, 2001, art. 24).

Kurator społeczny pełni funkcję społeczną i współpracuje z kuratorem zawodowym, nie jest pracownikiem sądu. Nie jest też organem ścigania ani or- 
ganem interwencyjnym. Swoje zadania wykonuje wyłącznie na podstawie przepisów prawa. Kuratorem społecznym może zostać osoba, która:

1) posiada obywatelstwo polskie i korzysta z pełni praw cywilnych i obywatelskich,

2) jest nieskazitelnego charakteru,

3) posiada stan zdrowia pozwalający na wykonywanie obowiązków kuratora społecznego,

4) posiada co najmniej średnie wykształcenie oraz doświadczenie w prowadzeniu działalności resocjalizacyjnej, opiekuńczej lub wychowawczej,

5) przedłoży informację z Krajowego Rejestru Karnego dotyczącą jego osoby (Ustawa, 2001, art. 84).

Kuratora społecznego powołuje, zawiesza w czynnościach i odwołuje prezes sądu rejonowego na wniosek kierownika zespołu. Kurator, po złożeniu ślubowania, pełni swoją funkcję społecznie w jednym zespole. Zakres jego zadań określa kierownik zespołu w porozumieniu z wyznaczonym kuratorem zawodowym, pod którego kierunkiem kurator społeczny ma pracować. Kurator społeczny może sprawować do 10 dozorów lub nadzorów (Ustawa, 2001, art. 87). W związku z wykonywaniem obowiązków służbowych kuratorowi społecznemu przysługują takie same uprawnienia co kuratorowi zawodowemu (Ustawa, 2001, art. 9). Należy on także do grona funkcjonariuszy publicznych, co daje mu ochronę prawną w związku z pełnioną funkcją. Prezes sądu może odwołać kuratora społecznego, jeżeli ten nienależycie wypełnia powierzoną mu funkcję lub wymagają tego względy organizacyjne, a także gdy przestaje on spełniać wymienione warunki konieczne dla wykonywania tej funkcji lub złożył on prośbę o zwolnienie (Ustawa, 2001, art. 88). $\mathrm{W}$ razie wszczęcia postępowania karnego przeciwko kuratorowi społecznemu, prezes sądu rejonowego zawiesza go w czynnościach (Ustawa, 2001, art. 89). O ile kuratorzy zawodowi są pełnoetatowymi pracownikami sądu i pobierają za swoją pracę wynagrodzenie, o tyle kuratorzy społeczni pełnią swoje czynności w ramach funkcji społecznej. Kuratorowi społecznemu przysługuje miesięczny ryczałt $\mathrm{z}$ tytułu zwrotu kosztów ponoszonych w związku ze sprawowanym przez niego nadzorem lub dozorem (Ustawa, 2001, art. 90; Śpiewak, 1999, s. 47, 59-62). 


\section{KuRATEla SĄDOWA W PRZEPISACH PRAWA}

O kurateli stanowi ustawa z 25 lutego 1964 r. - Kodeks rodzinny i opiekuńczy (Dz.U. z 1964 r. nr 9, poz. 59 z późn. zm.). Kuratora ustanawia się w wypadkach przewidzianych w ustawie (art. $178 \$ 1$ ). W sprawach, które nie zostały uregulowane swoiście, dla kurateli zastosowanie mają odpowiednio przepisy o opiece. Status prawny kuratorów sądowych regulują przede wszystkim: ustawa o kuratorach sądowych (Dz.U. z 2018 r. poz. 1014), ustawa z 27 lipca 2001 r. - Prawo o ustroju sądów powszechnych (Dz.U. z 2001 r. nr 98, poz. 1070 z późn. zm.) oraz cały wiele aktów podstawowych odnoszących się do pozycji kuratorskiej służby sądowej w strukturze wymiaru sprawiedliwości, zadań kuratorów sądowych wspólnych dla kuratorów dla dorosłych i kuratorów rodzinnych oraz dotyczących organizacji kurateli (Dz.U. z 2015 r. poz. 2316; Dz.U. nr 239, poz. 2037 z późn. zm.; Dz.U. nr 116, poz. 1100; Dz.Urz. Ministra Sprawiedliwości z 2003 r. Nr 5 poz. 22). Wśród innych ustaw wyznaczających w różnym zakresie zadania i obowiązki należy wymienić: Kodeks karny, Kodeks karny wykonawczy, Kodeks postępowania karnego, Kodeks karny skarbowy, Kodeks wykroczeń, ustawę o postępowaniu w sprawach nieletnich, ustawę o wychowaniu w trzeźwości i przeciwdziałania alkoholizmowi, Kodeks rodzinny i opiekuńczy, Kodeks postępowania cywilnego, a także liczne rozporządzenia i zarządzenia wydane przez właściwe organy państwowe w celu wykonania ich ustawowych delegacji.

Z przepisów ogólnych ustawy wynika, że „kuratorzy sądowi realizują określone przez prawo zadania o charakterze wychowawczo-resocjalizacyjnym, diagnostycznym, profilaktycznym i kontrolnym, związane z wykonywaniem orzeczeń sądu" (Ustawa, 2001, art. 1). Kuratorzy sądowi wykonują swoje zadania w środowisku podopiecznych, także na terenie zamkniętych zakładów i placówek ich pobytu, w szczególności na terenie zakładów karnych, placówek opiekuńczo-wychowawczych oraz leczniczo-rehabilitacyjnych. Za podopiecznych, o których mowa w ust. 1, uważa się osoby, których dotyczy postępowanie (Ustawa, 2001, art. 3.1). Ponadto ustawa o kuratorach sądowych z 271 ipca 2001 r. określa: status kuratora sądowego, w tym jego pozycję w wymiarze sprawiedliwości (rozdział 1 ustawy o kuratorach zawodowych), warunki ubiegania się o status kuratora, wynagrodzenia kuratorów, zasady zawieszenia kuratora w pełnieniu obowiązków (rozdział 2), organizację kuratorskiej służby sądo- 
wej (rozdział 3), organizację samorządu kuratorskiego (rozdział 4), odpowiedzialność sądową i dyscyplinarną kuratorów zawodowych (rozdział 5), zasady naboru na aplikację kuratorską, cele aplikacji, przebieg egzaminu (rozdział 6), warunki ubiegania się o status kuratora społecznego (Ustawa, 2001).

\section{UPRAWNIENIA KURATORA WYKONUJĄCEGO SWOJE ZADANIA}

Mówiąc o uprawnieniach kuratora, konieczne jest omówienie jego praw i obowiązków wynikających z ustawy, a także zadań, które są ściśle związane $\mathrm{z}$ nadzorem kuratorskim.

Kuratorowi zawodowemu przysługują następujące prawa:

1) do odwiedzin podopiecznych w godzinach od 7.00 do 22.00 ,

2) do żądania okazania dowodu tożsamości od podopiecznego,

3) do żądania niezbędnych wyjaśnień i informacji,

4) do przeglądania akt sądowych i sporządzania $z$ nich odpisów oraz dostępu do dokumentacji dot. podopiecznego i innych osób objętych postępowaniem,

5) do żądania od Policji oraz innych organów lub instytucji państwowych, organów samorządu terytorialnego, towarzyszeń i organizacji społecznych oraz osób fizycznych pomocy w wykonywaniu obowiązków służbowych (Ustawa, 2001, art. 9).

Do obowiązków kuratora zawodowego należy:

1) występowanie w uzasadnionych przypadkach $\mathrm{z}$ wnioskiem o zmianę lub uchylenie orzeczonego środka,

2) przeprowadzanie wywiadów środowiskowych,

3) współpraca z osobami, które statutowo zajmują się opieką, wychowaniem, resocjalizacją, leczeniem i świadczeniem pomocy społecznej w środowisku otwartym,

4) organizacja działań i kontrola podległych kuratorów społecznych oraz innych osób wykonujących dozory lub nadzory,

5) sygnalizowanie sądowi przyczyn przewlekłości postępowania wykonawczego lub innych uchybień w działalności pozasądowych podmiotów wykonujących orzeczone środki (Ustawa, 2001, art. 11). 
Kuratorzy społeczni są funkcjonariuszami publicznymi, a ich uprawnienia są takie same jak kuratorów zawodowych. Wymogi psychologiczno-fizyczne są takie jak dla kuratorów zawodowych. „To społeczni funkcjonariusze publiczni coraz lepiej przygotowani i coraz lepiej wykonujący pod kierunkiem profesjonalistów swoje powinności. Nie bez znaczenia jest fakt, że kilkadziesiąt tysięcy osób tkwiących w środowiskach lokalnych uczestniczy aktywnie w zapobieganiu przestępczości, profilaktyce, udzielaniu pomocy pokrzywdzonym i ochronie prawnej" (Rzepniewski, 2010, s. 86).

Nadrzędnym zadaniem kuratora jest sprawowanie orzeczonego przez sąd nadzoru/dozoru kuratorskiego. Związany z tym zadaniem zestaw czynności i obowiązków nie jest już uwarunkowany postępowaniem sądowym, lecz tylko realizacją postanowienia sądu. W tym zakresie kurator jest autonomicznym podmiotem działania, specjalistą w zakresie realizacji zadań korekcyjnych, wychowawczych, edukacyjnych i terapeutycznych (Sawicka, 2010, s. 132). W realizacji nadzoru stosuje się wiele form i metod działania, za najpowszechniejszą uznaje się metodę indywidualnych przypadków.

Kurator w pierwszej kolejności podejmuje działania diagnostyczne, zmierzające do określenia głównego problemu, przyczyn niekorzystnego funkcjonowania społecznego, stanu środowiska wychowawczego pod kątem jego możliwości realizacji celów wychowawczych i korekcyjnych. Następnie sporządza plan postępowania korekcyjnego i wychowawczego, by na jego podstawie prowadzić indywidualną pracę z podopiecznym lub jego rodziną (Sawicka, s. 132). Obok zadań o charakterze resocjalizacyjnym kuratorzy wspomagają sąd w podjęciu sprawiedliwej i korzystnej dla podopiecznego decyzji, dostarczając na jego zlecenie niezbędnych danych czy propozycji. Wzajemne przenikanie się tych dwóch podstawowych ogniw systemu resocjalizacji wskazuje na integralny i komplementarny związek sędziów z kuratorami sądowymi pomimo istotnych różnic. Wspólnym celem oddziaływań jest przede wszystkim transformacja postawy podopiecznego $\mathrm{z}$ antyprawnej na prospołeczną. Kuratorzy współpracują z właściwymi samorządami i organizacjami zajmującymi się opieką, wychowaniem lub pomocą społeczną. $\mathrm{W}$ razie konieczności występują z wnioskiem o zmianę lub uchylenie orzeczonego środka, organizują i kontrolują pracę podległych im kuratorów lub innych osób i sygnalizują sądowi ewentualne uchybienia. 
Poza obowiązkami każdy kurator wykonujący swoją pracę ma również wiele praw. Kurator zawodowy w celu realizowania zadań, obok żądania okazania przez osoby objęte postępowaniem dokumentów stwierdzających tożsamość, może wymagać od nich informacji czy wyjaśnień. Z uwagi na charakter wykonywanej pracy kurator zawodowy ma również prawo do przeglądania akt sądowych. Kuratorzy społeczni pracują w określonym zespole, a ich zadania wyznaczane są przez kierownika grupy w porozumieniu z wyznaczonym kuratorem zawodowym. Kurator społeczny ma podobny zakres obowiązków, ma też analogiczne uprawnienia w zakresie odwiedzania osób objętych postępowaniem i sporządzania dokumentacji ze swojej pracy.

\section{METODY PRACY KURATORA}

Odpowiedzialne sprawowanie nadzorów nad powierzonymi przez sąd podopiecznymi wymaga wykorzystywania przez kuratora wielu metod i form pracy. Podstawowym zadaniem kuratorów sądowych jest diagnozowanie podsądnych i ich środowisk rodzinnych na potrzeby sądów, prokuratury, policji i więziennictwa, a także prowadzenie szeroko pojętej resocjalizacji, która ma na celu ugruntowanie w osobie dozorowanego (lub nadzorowanego) właściwych wzorców zachowań, nastawienia na życie zgodne z obowiązującymi normami prawnymi i społecznymi. Współczesny model postępowania z podopiecznymi można określić modnym w niektórych środowiskach mianem: „zarządzanie i administrowanie zasobami ludzkimi” (Konopczyński, 2016).

Polski system postępowania z nieletnimi jest zdominowany przez podejście opiekuńcze, jego zaletą jest preferowanie dobra nieletniego, koncentrowanie się na jego potrzebach, rezygnacja z karania nieletnich przestępców na rzecz stosowania środków wychowawczych, leczniczych i poprawczych. Do wad należy rosnąca liczba nieletnich, wobec których sąd rodzinny stosuje środki wychowawcze z powodu demoralizacji oraz bezradność organów wykonujących niektóre środki wychowawcze orzeczone wobec starszych nieletnich.

W swojej działalności kuratorzy posługują się zasadniczo trzema formami metodycznymi: casework, groupwork i network. Praca metodą indywidualnych przypadków, a więc metoda casework (Gromek, 2002, 
s. 30), jest najbardziej popularna i rozpowszechniona. Polega na stosowaniu oddziaływań o charakterze psychotechnicznym i sprowadza się w swojej praktycznej istocie do doradztwa i mediacji indywidualnych i społecznych. Casework jest „sztuką, w której wiedza życiowa i nauka o człowieku oraz środowisku, a także umiejętność obcowania z ludźmi - są użyte w celu zmobilizowania sił w jednostce i odpowiedniej pomocy w społeczeństwie dla ulepszenia wzajemnego przystosowania się jednostki i jej środowiska" (Kalinowski, 1984, s. 160). Metoda pracy z indywidualnym przypadkiem bazuje na psychotechnice, czyli wykorzystaniu specyficznych zależności w relacji kurator - osoba nadzorowana. Wśród sposobów postępowania $\mathrm{w}$ tej relacji wymienia się metody: a) pobudzające (informowanie, dostarczanie wzorów osobowych, stosowanie zaleceń, wyrażanie sugestii, doradzanie wychowawcze, przekonywanie), b) ukierunkowujące (przekazywanie decyzji, kontrola), c) podtrzymujące aktywność podopiecznego (organizowanie doświadczeń, metoda wpływu osobistego, oddziaływanie dyscyplinujące) (Zinkiewicz, 2015, s. 20-21). Bardzo istotny jest kontakt z kuratorem oparty na zaufaniu, szczerości i silnej więzi emocjonalnej, a także uznawanie ważnych zasad:, np. zasady „twarzą w twarz”, zasady akceptacji, optymizmu pedagogicznego (wywołanie właściwej motywacji i hierarchii wartości), zasady respektowania (motywowanie podopiecznego do wewnętrznej przemiany swojej osobowości i dotychczasowego życia) oraz zasady indywidualizacji (praca dostosowana do indywidualnych potrzeb podopiecznego) (Bębas, 2014, s. 138). Kurator udziela pomocy czynnej i wsparcia we wszystkich wysiłkach zmierzających do poprawy życia podopiecznego, planowania przyszłości, wyznaczania celów i organizowania całokształtu procesów zmierzających do podjęcia określonych życiem ról w społeczeństwie (Bębas, s. 139).

Metoda pracy grupowej groupwork jest stosowana głównie w kuratorskich ośrodkach pracy z młodzieżą i polega na oddziaływaniach o charakterze socjotechnicznym, grupowych metod kulturo-technicznych, aktywizujących itp., do których zalicza się m.in.: dramę, socjodramę, „burzę mózgów”, krąg i rundki, śpiew i muzykowanie, twórczość plastyczną, gry i zabawy ruchowe i inne. Wszystkie elementy oddziaływań powinny być wzajemnie powiązane. Metody te prowadzą do zaktywizowania grupy i wyzwolenia jej poten- 
cjału twórczego, odblokowania napięć psychicznych wychowanków, wyrażenia siebie, swoich uczuć i przeżyć, sprzyjają lepszemu porozumiewaniu się, wykorzystując kod pozawerbalny. Poza tym wszelkie gry i zabawy ruchowe dostarczają uczestnikom grupy pozytywnych wrażeń - nieskrępowanej radości, swobodnej ekspresji, odprężenia psychicznego i fizycznego (Rapa, 2012, s. 66-70). Jest wiele form pracy grupowej, które ustala prowadzący zajęcia, biorąc pod uwagę potrzeby, wiek i problemy grupy.

Metoda network polega na wymianie informacji i integrowaniu kontaktów pomiędzy podopiecznymi, ich rodzinami, szkołą oraz instytucjami kontroli, wsparcia i pomocy społecznej (Konopczyński, 2010, s. 39). Współpracę różnych osób i instytucji w środowisku lokalnym prowadzi się w celu tworzenia sieci wsparcia, jako skutecznego antidotum na pojawiające się różnorodne kryzysy życiowe. Działania na rzecz pomocy i wsparcia dla jednostki powinny być podejmowane przez osoby pracujące w różnych instytucjach, specjalistów reprezentujących różne dziedziny wiedzy, w tym psychologię, pedagogikę, terapię rodzinną, pracę socjalną oraz prawo.

Oddziaływania kuratora przybierają odmienny charakter w zależności od tego, czy są one kierowane do osób dorosłych czy dzieci, których dobro jest zagrożone przez działania ich rodziców, lub nieletnich przejawiających oznaki nieprzystosowania społecznego. Taka duża różnorodność wymaga specyficznego podejścia do pracy z podopiecznymi oddanymi pod nadzór (lub dozór) kuratora.

\section{Podsumowanie}

Konkludując, polska kuratela sądowa jest instytucją nowoczesną, doskonale łączącą instytucje i specjalizacje, które przez dziesięciolecia funkcjonowały w izolacji od siebie. Systemowe podejście do problemu wymaga potraktowania go w sposób kompleksowy, uwzględniający nie tylko jednostkę, ale również otaczające ją systemy, w tym w szczególności rodzinny i lokalny. Aktualnie wyraźnie zaznacza się współpraca kuratorów z przedstawicielami różnych służb, co przekłada się korzystnie nie tylko na funkcjonowanie podopiecznych, ale także całej społeczności lokalnej. Nawiązywanie współpracy $\mathrm{z}$ instytucjami usytuowanymi w środowisku podopiecznego jest aktywnością pośrednią, która powoduje nieustanną potrzebę „bycia w dialogu” kurateli 
rodzinnej z innymi podmiotami społecznymi. Z kolei aktywność bezpośrednia kuratora sądowego polega na sprawowaniu opieki nad podopiecznym w jego miejscu zamieszkania lub pobytu (Rapa, 2012, s. 115). Współczesna kuratela sądowa jest więc metodą indywidualnego i społecznego działania wychowawczego w celu doprowadzenia do jego poprawy i ukształtowania u dozorowanego prawidłowych cech charakteru. Efektem działań kuratora jest przygotowanie podopiecznego do dokonywania samodzielnych wyborów, które przynosiłyby pożytek zarówno jemu, jak i społeczności, w której żyje. Aby oddziaływanie miało charakter pełny i efektywny należy dysponować środkami wpływu osobistego i grupy wychowawczej, dobrami kultury i cywilizacji współczesnej, którymi można modyfikować przekonania i zachowania osób nieprzystosowanych społecznie.

W kurateli wyróżnia się dwa zasadnicze modele pracy związane z zakresem i charakterem działań kuratorów. Jest to model kurateli wychowującej i model kontrolno-represyjny. Pierwszy polega na nawiązaniu przez kuratora przyjaznej relacji z podopiecznym, dzięki której możliwe jest wykształcenie w nim właściwych postaw i wartości, a także zmiany jego dotychczasowego zachowania. Drugi model oparty jest głównie na sprawowaniu przez kuratora kontroli nad osobą objętą nadzorem (lub dozorem). Występuje również model mieszany, w którym występują elementy kontrolne, terapeutyczne i wychowawczo-resocjalizujące (Bałandynowicz, 1982, s. 180; Gromek, 2002, s. 10-11). Z kolei dla określenia struktury zatrudnienia kuratorów sądowych wyróżnia się: model społeczno-zawodowy lub zawodowo-społeczny kurateli sądowej (Węgliński i Duński, 1993, s. 19; Stańdo-Kawecka, 2000 s. 216; Gromek, 2002, s. 22). Wszelkie działania kuratorów są podejmowane wyłącznie $\mathrm{w}$ ramach obowiązujących norm prawnych.

Kiedyś kuratorom przypisywano wyłącznie funkcje administracyjne, sytuowano ich w pionie administracyjnym, dzisiaj kuratela jest służbą publiczną i zawodem. Kuratela tworzy dynamiczny układ społeczny w postaci resocjalizacji wolnościowej. Obok mediacji i kary ograniczenia wolości zaliczana jest do najczęściej stosowanych środków alternatywnych, czyli środków przeciwstawnych izolacji społecznej podsądnych. Kurator jest organizatorem procesu wychowania resocjalizacyjnego, tworząc dwustronny kontakt z podopiecznym. 


\section{Literatura}

Bachmat, P. [et.al], red. nauk. Dobrochna Wójcik. (2010). Kuratela sądowa: sukcesy i porażki. Warszawa: Wydawnictwo Naukowe Scholar. ISBN 9788373834071.

Bałandynowicz, P. (2015). Probacja resocjalizacyjna z udziałem społeczeństwa. Wydawnictwo: Wolters Kluwer Polska S.A., s. 19. ISBN 9788326414916.

Bałandynowicz A. (1982). Kliniczny model kurateli sadowej w warunkach nadzoru ochronnego. „Studia Kryminologiczne, Kryminalistyczne i Penitencjarne” t. 12, s. 180. ISSN 0137-5458.

Bębas, S. (2014). Metody i formy oddziatywań wychowawczych kuratorów sądowych. Lubelski Rocznik Pedagogiczny t. XXXII I, s. 138, [online] file://C:/Users/s26/Downloads/184-274-1-SM.pdf [dostęp 26.01.2019].

Borowski, R., Wysocki D. (2001). Instytucje wychowania resocjalizującego. Płock: Wydawnictwo Naukowe „Novum”, s. 137-139. ISBN 8388193279.

Górecki, P. (1997). Postępowanie poprawcze w sprawach nieletnich. Sopot: Wydawnictwo Prawnicze Lex, s.28. ISBN 9788381604802.

Gromek, K. (2002). Kuratorzy sądowi. Komentarz do ustawy z dnia 27 lipca 2001 r. Warszawa: Wydawnictwo Prawnicze „LexisNexis”, s.10-11, 22, 30. ISBN 8373340793.

Jedynak, T., Stasiak, K. (red.). (2008). Zarys metodyki pracy kuratora sądowego. Warszawa: Wydawnictwo Prawnicze „LexisNexis”. ISBN 9788376204352.

Jedynak, T., Martuszewicz, A. (2008). Od rozporzadzenia do ustawy o kuratorach sadowych, [w:] Jedynak T., Stasiak K. Zarys metodyki pracy kuratora sadowego. Warszawa: Wydawnictwo Prawnicze „LexisNexis”. ISBN 9788376204352.

Jedynak, T., Stasiak K. (2009). Komentarz do ustawy o kuratorach sadowych. Warszawa: Wydawnictwo Prawnicze „LexisNexis”. ISBN 9788376200293.

Jurczyk, D. (2017). Rola kuratora zawodowego w procesie readaptacji osób skazanych/ ukaranych wykonujacych nieodpłatna kontrolowana prace na cele społeczne oraz pracę społecznie użyteczną. Katowice: Uniwersytet Śląski, s. 17 [online], https://sbc. org.pl/Content/306309/doktorat3948_Danuta_Jurczyk.pdf [dostęp 24.01.2019].

Kalinowski, M. (1984). Vademecum rodzinnego kuratora sadowego. Warszawa: Instytut Wydawniczy Związków Zawodowych, s. 160. ISBN 8320203244.

Kalinowski, M. (1990). Nadzór kuratora sądowego - forma wychowania resocjalizacyjnego. Powstanie i rozwój kurateli sądowej dla nieletnich, [w:] K. Pospiszyl (red.). Resocjalizacja nieletnich. Doświadczenia i koncepcje. Warszawa: WSiP, s. 26, 284. ISBN 8302041092. 
Kępka, S. (2007). Kuratela sq̨dowa: wychowująca czy kontrolno-represyjna? Ujęcie formalnoprawne, [w:] Bielecka E. (red.). Profilaktyka i readaptacja społeczna - od teorii do doświadczeń praktyków. Białystok: Wydawnictwo Uniwersyteckie Trans Humana, s. 95. ISBN 9788389190925.

Konopczyński, M.[et. al.]; rec.: Beata Pastwa-Wojciechowska (2016). Polska kuratela sądowa na przełomie wieków: nadzieje, oczekiwania, dylematy. Kraków: Oficyna Wydawnicza „Impuls”. ISBN 9788380950122.

Konopczyński, M. (2010). Resocjalizacyjna rola kuratora sądowego, [w:] Konferencja 90 lat kurateli sądowej w Polsce Historia - teraźniejszość - przyszłość. Warszawa: Wydawnictwo Sejmowe, s. 39. [online] http://kurator.webd.pl/wp-content/uploads/2010/09/90-lat-kurateli-sadowej-w-polsce-historia-terazniejszosc-przyszlosc.pdf [dostęp 26.01.2019].

Kowalska-Ehrlich, B. (1979). Zasady postępowania z nieletnimi, [w:] A. Krukowski (red.). Prawne podstawy resocjalizacji i zapobiegania przestępczości. Warszawa: PWN, s. 228. ISBN 8301008806.

Królikowska, J. (2006). Kontekst socjologiczny pracy kuratora sądowego, [w:] E. Bielecka (red.). Profilaktyka i readaptacja społeczna - od teorii do doświadczeń praktyków. Białystok: Wydawnictwo Trans Humana, s. 271-285. ISBN 9788389190925.

Kufel, J. (2011). Działalność kuratorów sądowych - rozważania w zakresie ustawodawstwa i praktyki. Łódź: Studia Prawno-Ekonomiczne, t. LXXXIII, s. 133-148.

[online]file:///C:/Users/s26/Downloads/Dzia\%20alno\%20\%20\%20kurator\%C3\%B3w\%20s\%20dowych\%20\%20\%20rozwa\%20ania\%20w\%20zakresie\%20 ustawodawstwa\%20(8).pdf [dostęp 24.01.2019].

Kwadrans, Ł. (2010). 90 lat kurateli sądowej w Polsce. Historia - teraźniejszość - przyszłość. Warszawa: „Probacja”, nr 3-4, s. 122. ISSN 1689-6122.

Marzec-Holka, K. (1994). Instytucja społecznych kuratorów sądowych w świetle badań. Bydgoszcz:Wydawnictwo Uczelniane WSP, s. 146. ISBN 8370960987.

Mazurek, W. (2014). Kuratela sądowa w kształtowaniu warunków bezpieczeństwa dzieci i młodzieży. Kraków: Wydawnictwo WAM. ISBN 9788327701916.

Pawlicka, M. (2007). Kuratela sądowa w Polsce, Europie i świecie - historia i stan obecny. Warszawa: Wydawnictwo Impuls 2007. ISBN 9788360856048.

Rapa, N. (2012). Rozwój instytucji kurateli rodzinnej w Polsce. KUL: „Rozprawy Społeczne”, nr 2 (VI), s. 66-74, 116-116, 118, 120-121. ISSN 2081-6081.

Rzepniewski, A. (2010). Prace nad ustawa o kuratorach sądowych z perspektywy dziesięciolecia. Doświadczenia z pracy $w$ zespole Ministerstwa Sprawiedliwo- 
ści oraz podkomisji Sejmu RP ds. ustawy o kuratorach, [w:] K. Stasiak (red.). 90 lat kurateli sądowej $w$ Polsce. Kraków: Wydawnictwo Impuls, s. 86. ISBN 9788376660226.

Sawicka, K. (2010). Model kurateli sąowej. Podstawowe założenia i źródła inspiracji [w:] K. Stasiak (red.). 90 lat kurateli sądowej w Polsce. Kraków: Wydawnictwo Impuls, s. 132. ISBN 9788376660226.

Stańdo-Kawecka, B. (2000). Prawne podstawy resocjalizacji. Kraków: Zakamycze, s. 216. ISBN 8388114840.

Stasiak, K. (2009). Ewolucja kurateli sadowej od początku do wejścia w życie rozporzadzenia z 1986 r., [w:] T. Jedynak, K. Stasiak (red.). Zarys metodyki pracy kuratora sadowego. Warszawa: Wydawnictwo LexisNexis. ISBN 9788376204352.

Stasiak, K. (2018). Kuratela sądowa w Polsce: analiza systemu. Ksiega pamiątkowa dedykowana doktorowi Tadeuszowi Jedynakowi. Toruń: Wydawnictwo Adam Marszałek.

Stępniak, P. (1992). Funkcjonowanie kurateli sadowej. Teoria i rzeczywistość. Poznań: UAM. ISBN 832320473X.

Szymków, K. (2018). Instytucja stałych opiekunów sądowych 1919-1929. Folia Iuridica Universitatis Wratislaviensis, s. 61-82. ISSN 2299-8322.

Śpiewak, J. (1999). Kurator sadowy w postępowaniu karnym wykonawczym. Poradnik dla sprawujacych dozory. Warszawa: Wydawnictwo Prawnicze, s. 47, 59-62. ISBN 832191019X.

Utrat-Milecki, J. (2010). Ethos zawodowego kuratora sadowego, [w:] K. Stasiak (red.). 90 lat kurateli sądowej. Kraków: Wydawnictwo Impuls, s. 168. ISBN 9788376660226.

Węgliński, A. Duński, A. (1993). Identyfikacja z zawodem rodzinnych kuratorów zawodowych. O reformie stużb kuratorskich w Polsce. „Opieka Wychowanie Terapia” nr 4, s. 19-26. ISSN 1230-0861.

Zinkiewicz, B. (2015). Profilaktyczny wymiar działalności rodzinnych kuratorów sadowych. Kraków: Oficyna Wydawnicza AFM, s. 20-21. ISBN 9788375713060.

\section{Akty prawne:}

Dekret Naczelnika Państwa z 7 lutego 1919 r. (Dz.Praw z 8 lutego 1919 r. nr 14, poz. 171).

Ustawa z 25 lutego 1964 r. - Kodeks rodzinny i opiekuńczy (Dz.U. z 1964 r. nr 9, poz. $59 \mathrm{z}$ późn. $\mathrm{zm}$.). 
Ustawa z 26 października 1982 r. o postępowaniu w sprawach nieletnich (Dz.U. z 1982 r. nr 35, poz. 228 z późn. zm.).

Ustawa z 20 czerwca 1985 r. - Prawo o ustroju sądów powszechnych (Dz.U. z 1994 r. nr 7, poz. $25 \mathrm{z}$ późn. zm.).

Ustawa z 6 czerwca 1997 r. - Kodeks karny wykonawczy (Dz.U. z 1997 r. nr 90, poz. 557 z późn. zm.).

Ustawa o kuratorach sądowych z 27 lipca 2001 r. (Dz.U. nr 98, poz. 1071).

Ustawa o ustroju sądów powszechnych z 27 lipca 2001 r. (Dz.U. z 2001 r. nr 98, poz. 1070).

Rozporządzenie Ministra Sprawiedliwości z 26 lipca 1919 r. w przedmiocie urządzenia sądów dla nieletnich (Dz.U. z 1919 r. nr 63, poz. 378).

Rozporządzenie Prezydenta Rzeczypospolitej z 11 lipca 1932 r. - Kodeks karny (Dz.U. z 1932 r. nr 60, poz. 571, art. $62 \S 1$ ).

Rozporządzenie Ministra Sprawiedliwości z 1 kwietnia 1959 r. w sprawie wynagradzania kuratorów zawodowych dla nieletnich (Dz.U. z 1959 r. nr 26, poz. 164).

Rozporządzenie Ministra Sprawiedliwości z 13 lutego 1959 r. o kuratorach sądowych dla nieletnich. (Dz.U. nr 18, poz. 113).

Rozporządzenie Ministra Sprawiedliwości z 24 listopada 1986 r. w sprawie kuratorów sądowych (Dz.U. z 1986 r. nr 43, poz. 212 z późn. zm.).

Rozporządzenie Rady Ministrów z 23 grudnia 2002 r. w sprawie wynagrodzeń kuratorów zawodowych i aplikantów kuratorskich (Dz.U. nr 239, poz. 2037 z późn. zm.).

Rozporządzenie Ministra Sprawiedliwości z 9 czerwca 2003 r. w sprawie standardów obciążenia pracą kuratora zawodowego (Dz.U. nr 116, poz. 1100).

Rozporządzenie Ministra Sprawiedliwości z 23 grudnia 2015 r. - Regulamin urzędowania sądów powszechnych (Dz.U. z 2015 r. poz. 2316).

Zarządzenie Ministra Sprawiedliwości z 12 grudnia 2003 r. w sprawie organizacji i zakresu działania sekretariatów sądowych oraz innych działów administracji sądowej (Dz.Urz. Ministra Sprawiedliwości z 2003 r. nr 5, poz. 22).

Obwieszczenie Marszałka Sejmu Rzeczypospolitej Polskiej z 9 maja 2018 r. w sprawie ogłoszenia jednolitego tekstu ustawy o kuratorach sądowych (Dz.U. z 2018 r. poz. 1014). 


\section{Endnotes}

1 Wynalezienie systemu probation przypisuje się sędziom okręgu Warwickshire, którzy już w 1820 r. zaczęli eksperymentalnie stosować skazywanie nieletnich na symboliczną karę jednego dnia więzienia, pod warunkiem że rodzice bądź opiekunowie wzmogą nadzór i wysiłki wychowawcze.

2 Skazani dorośli obejmowani są dozorem, wobec nieletnich sprawuje się nadzory.

3 Dotychczasowe uregulowania zawarte były w kilku różnych aktach prawnych:

- w ustawie z 26 października 1982 r. o postępowaniu w sprawach nieletnich (Dz.U. z 1982 r. nr 35, poz. 228 z późn. zm.),

- w ustawie z 20 czerwca 1985 r. - Prawo o ustroju sądów powszechnych (Dz.U. z 1994 r. nr 7, poz. 25 z późn. zm.),

- w ustawie z 6 czerwca 1997 r. - Kodeks karny wykonawczy (Dz.U. z 1997 r. nr 90, poz. 557 z późn. zm.),

- w rozporządzeniu Ministra Sprawiedliwości z 24 listopada 1986 r. w sprawie kuratorów sądowych (Dz.U. z 1986 r. nr 43, poz. 212 z późn. zm.). 